\author{
Is Georgia the next 'new' wine-exporting country? \\ Kym Anderson \\ University of Adelaide, Australian National University and CEPR
}

RMI-CWE Working Paper number 1301

January 2013

Paper for a seminar at the Center for Wine Economics, Mondavi Institute, UC Davis, 28 January 2013. An earlier version was presented at a World Bank-wine industry seminar, Tbilisi, Georgia, 9 March 2012 and at the Wine Pre-Conference Workshop, ICABR-EAAE Conference, Feudi di San Gregorio, Italy, 24 June 2012. The author is grateful for discussions with many people in Georgia and at the workshop, and for financial support from the World Bank and Australia's Grape and Wine Research and Development Corporation. The views expressed are the author's alone.

(C) Copyright 2013 by Kym Anderson. All rights reserved. Readers may make verbatim copies of this document for non-commercial purposes by any means provided that this copyright notice appears on all such copies. 


\begin{abstract}
The former Soviet republic of Georgia is reputedly the cradle of wine and has enjoyed at least 8000 vintages. It has also been a major supplier of wine to Russia for at least 200 years, but to few other countries. In 2006, however, Russia imposed a ban on beverage imports from Georgia. Since then this relatively poor country, in which nearly half the population is rural and most farmers (average holding 1.2 ha) have a vineyard, has been seeking to develop new export markets for its wine. This paper assesses the potential for growth in Georgia's wine production and exports. It then outlines ways to addresses the challenges involved in trying to realize that potential, drawing on the experience of other countries that have expanded their wine exports in the past two decades. Implications for policy are drawn out in the final section.
\end{abstract}

Keywords: Export-led growth; rural development in transition; wine trade embargo

JEL codes: F14, F15, F54, Q17

\title{
Author contact:
}

Kym Anderson, Executive Director

Wine Economics Research Centre

School of Economics

University of Adelaide

Adelaide SA 5005 Australia

Phone +61 883134712

Fax +61882231460

kym.anderson@adelaide.edu.au 


\section{Is Georgia the next 'new' wine-exporting country?}

\section{Introduction}

Georgia, a country wedged between the Black and Caspian seas at the same latitude as the south of France, is reputably the cradle of wine (McGovern 2003, 2009). It has experienced 8000 vintages, is blessed more than 500 indigenous Vitis vinifera winegrape varieties, and has an enviable reputation for hospitality involving lavish and lengthy feasts (supra). In 2005 wine accounted to almost one-tenth of the value of all goods exported from Georgia, making wine exports around six times as economically important as in France, Italy and Spain. Moreover, virtually every Georgian farm household grows grapes and produces wine, and they represent nearly half the country's households and employment and most of the poverty in this relatively poor nation in which one-third of the population survives on less than $\$ 2$ a day.

For the past two centuries, including the Soviet era, Georgia has been a major supplier of wine to Russia and other members of the Commonwealth of Independent States. However, because very little Georgian wine has been exported elsewhere, it was a major blow when Russia, for political reasons, introduced a ban on wine imports from Georgia in 2006. As of mid-November 2012 that embargo was still in place, although there is speculation it might be lifted following the change of government in Georgia the previous month. That shock (compounded by the short war with Russia in August 2008) has required Georgian wine exporters to develop markets elsewhere, a task made considerably more difficult by the emergence of the global financial crisis from 2008, and by a 40 percent devaluation against the US\$ in late 2008 by Ukraine (to which half of Georgia's wine exports were then destined). Nonetheless, in November 2011 the Minister of Agriculture at that time announced that he wanted to see a near-trebling of wine exports by 2015, and the country's wine industry says they want to diversify to other markets regardless of whether Moscow lifts its embargo.

This paper explores the prospects for growth in wine exports from Georgia. It begins in Section 2 with a brief description of key indicators of Georgia's economy relative to those of its neighbors, highlighting the extraordinary importance of wine within the economy. That 
provides the background needed to assess the potential for growth in Georgia's wine production and exports, which is the focus of Section 3. Realizing that potential, however, will require the government and industry to work together on a wide range of fronts to attract the various crucial investments required. Those necessary conditions are drawn out in Section 4, based on the experience of other countries that have expanded their wine exports in the past two decades. The final section summarizes the paper's findings and lists several implications for policy, not least for ensuring that poverty is reduced as exports expand and the economy grows.

\section{Key indicators of Georgia's economy and of wine's importance}

The economy of Georgia is very open and by far the easiest in the region in which to do business. Its exports plus imports of goods and services amounted to 87 percent of its GDP in 2010 when, according to the World Bank (2011a), it was ranked $16^{\text {th }}$ out of 183 countries in terms of ease of doing business - and was the most-improved in the world over the past five years.

Yet apart from Moldova, Georgia has the lowest national income per capita of the countries in the region bordering the Black and Caspian seas, and has one of the region's most skewed distributions of income and the largest proportion of households in poverty (World Bank 2011b).

Agricultural wages are around one-third those of non-farm workers, and the incidence of poverty is nearly twice as high in rural as in urban areas. This is not surprising given that the farm sector is dominated by small private farms with an average size of 1.2 hectares (93 percent are less than 2 hectares). Even so, semi-subsistence agriculture, which accounts for three-quarters of rural employment, is the main source of income for the majority of rural households, together with public transfers (World Bank 2009). Most farmers have a vineyard and produce wine for self-consumption with family and friends, and some small and medium farm enterprises also sell grapes to commercial wineries, often under contract. Between 92 and 95 percent of the country's grapes are grown on family farms, and grapes account for around two-fifths of the volume of all fruit produced in Georgia. All but 8 percent of grapes are used for wine, the rest being for table grapes (NSO 2011a, b).

The value of Georgia's wine output, including for subsistence consumption, amounted in 2009 to 0.7 percent of GDP, which is similar to that in Argentina and South Africa, only a 
little below France and Portugal's 0.9 percent and Chile’s 1.2 percent, but well below Moldova’s 4.6 percent (Anderson and Nelgen 2011, Tables 86 and 159).

Most non-farm households in Georgia also consume wine as their alcoholic beverage of choice. Although it is commonly purchased from bulk containers rather than in labeled bottles, an expanding number of private wineries are developing brands and selling labeled bottles in the domestic market (while exported wine is shipped mainly in bottles). During 2006-10, exports comprised almost one-fifth of total wine production, and nearly two-thirds of labeled bottles. Domestic wine consumption per adult, including from self-production, is estimated to be around 17 litres in 2009. Wine is thus a non-trivial part of domestic household spending on food, beverages and tobacco, which in 2010 accounted for 46 and 39 percent of Georgian rural and urban household expenditure, respectively.

Wine contributes to all three key sectors of the economy: primary production (grape growing), manufacturing (grape processing into wine and also brandy and chacha/grappa) and services (transporting of grapes and wine, marketing of wine, and the various activities associated with wine tourism). Commercial wine tourism is not something that Georgians spend much time and money on (since it has long been mainstreamed into the culture), but many international visitors to Georgia indulge in food and wine tourism activities to some extent. This component of the wine-producing industry is beginning to take off as a services export revenue earner.

In the ten years to 2005, three-quarters of the country's wine export earnings came from Russia, and Ukraine boosted that share to 90 percent. More than two-thirds of the earnings from exports of distilled spirits (brandy and chacha) also came from Russia.

The decision by Russia in late March 2006 to ban imports of alcoholic beverages and bottled water from Georgia was therefore a major shock to the country’s overall economy, particularly to its rural areas and especially to its wine industry. ${ }^{1}$ The share of beverages in the total value of merchandise exports had grown from 11 to 15 percent in the first half of the past decade, but during 2009-11 it was only half that share. Bottled water exports also halved. Wine’s share of all goods and services exports fell from 5.4 to 1.3 percent between 2005 and 2010, and wine's share of just alcohol exports fell from 73 percent in 2005 to 33 percent in 2007, before recovering slightly to 40 percent in 2010: much of what would have been

\footnotetext{
${ }^{1}$ This was preceded by two previous shocks: the anti-alcoholism campaign launched by Mikhail Gorbachev in 1985 led to nearly three-quarters of Georgia's vineyards being uprooted; and the economic collapse of the early independence years post-1991 damaged the industry further via widespread counterfeiting of Georgian wine in Russia. At the mid-1980s peak, Georgia had around 120,000 hectares of grapevines. That is comparable with the area in the early 2000s in Australia, Bulgaria, Chile, Greece, Moldova and South Africa, and greater than in (East plus West) Germany.
} 
exported as wine was distilled, and exports of distilled alcohol doubled between 2005 and 2008 (NSO 2011c).

A striking feature of the Russian embargo is that Georgia's wine exports, while declining initially in quantity, have risen markedly in quality since 2006. Wine’s average export price was only US\$1 per litre in the late 1990s and \$2 during 2000-05, but by 2008 it averaged \$3.50 and, despite the global financial crisis, was as high as \$3.20 in 2011 (Figure $1)$.

Since the Russian embargo, the other CIS countries have dominated as destinations for Georgian wine exports. By 2010 half the exports were still going to Ukraine and another one-quarter to other CIS members. Poland and the three Baltic former Soviet states account for another one-eighth while the United States and China each have a 2 percent share and most of the rest goes to other EU members (GWA 2011). The current trade situation thus leaves a great deal of scope for diversifying Georgia’s wine export destinations, since the whole of Central and Eastern Europe plus the CIS (excluding Russia) accounted in 2005-09 for less than 7 percent of the volume of global wine imports, compared with more than 90 percent of wine exports from Georgia.

\section{Potential for growth in Georgia's wine production and export diversification}

In exploring the growth potential for Georgian wine exports, it is helpful to review the basic determinants of comparative advantage in wine and then examine the available data for Georgia compared with other wine-exporting countries.

\subsection{Determinants of comparative advantage in wine}

There are numerous determinants of a country's comparative advantage in wine production, but of particular importance for wine are the three T's of terroir, tradition, and technology.

Terroir refers to various pertinent aspects of climate, topography, soils, geology, etc. that determine the quality of the vine's growing conditions. Vineyard site selection therefore is crucial. Experience has determined the best sites and most-suitable grape varieties in longestablished regions, whereas in new regions science has to be used to speed the process of approaching the potential of any region to produce quality winegrapes (Gladstones 1992). 
While Georgia has many suitable regions for growing various winegrape varieties and styles for its traditional markets, they have yet to be proven for other export markets.

Traditions determine not only how a product is produced but also the extent of local consumer demand. This is important for wine because typically local demand is the easiest and least costly for producers to satisfy, as there are relatively high fixed costs of entry into new export markets (Friberg, Paterson and Richardson 2011) - especially with unfamiliar styles and varieties. In Georgia, where the tradition of drinking (mostly unlabelled) wine with meals is already pervasive, domestic demand absorbs much of the grapes produced. What has been available for processing into labelled commercial wine for export has been almost exclusively sold in the larger Soviet 'home' market which demanded a unique style of cheap semi-sweet red wine. Those two 'home market’ biases thus have not provided Georgia’s wineries with experience in producing for bottled wine markets elsewhere that are very different from their traditional markets.

As for technologies, there is always potential to improve on traditional production, processing, entrepreneurship and marketing, be that by trial and error of practitioners over the generations or via formal investment in private and public research and development (R\&D). The New World wine-producing countries have been more dependent on newly developed technologies than have producers in Western Europe, although both sets of countries have made major R\&D investments - and expanded complementary tertiary education in viticulture, oenology and wine marketing - over the past half-century (Giuliana, Morrison and Rabellotti 2011).

How important modern technologies are relative to terroir in determining comparative advantage is a moot point. One recent statistical study suggests terroir is not as dominant as is commonly assumed - even in regions as established as Bordeaux (Gerguad and Ginsburg 2008). Another study, of vineyard sale values in Oregon, finds that while appellation reputation has some economic value, each location's physical attributes are not closely related to wine prices (Cross, Plantinga and Stavins 2011). A recent book by Lewin (2010) begins its section on wine regions with the New World rather than the Old World, to emphasize the point that wines almost everywhere are manipulated by winemakers as they endeavour to make use of available knowledge to produce the products most desired by their customers. What they choose to produce is increasingly being affected by how they can maximize profits through satisfying consumer demand.

New technologies in agriculture have long tended to be biased in favor of saving the scarcest factor of production, as reflected in relative factor prices. Hayami and Ruttan (1985) 
emphasize that the focus of $R \& D$ investments thus has been driven in part by changes in factor prices, and in particular by the rise in real wages. That has resulted in the development and/or adoption of labour-saving technologies such as mechanical harvesters and pruners for vineyards and super-fast bottling/labelling equipment for wineries in land-abundant, labourscarce countries such as Australia. The adoption of labour-saving technologies has helped countries with rapidly rising real wages retain their comparative advantage in what traditionally had been labour-intensive industries. This in turn means poorer countries need to find sources of comparative advantage other than just low wages.

In Georgia, where real farm wages have remained relatively low, labour-intensive technologies such as qvevri-based production (an ancient organic method involving large clay storage vessels), in addition to hand pruning and harvesting, have persisted. This is not inconsistent with Hayami/Ruttan theory, but it does mean Georgia’s traditional wine technology is very different from - and not necessarily more internationally competitive than - that of higher-wage wine-exporting countries.

Relative factor endowments also affect the comparative advantage of a country in terms of the quality of its exported products. New trade theory suggests richer, capitalabundant countries will export higher priced, higher-quality goods (Fajgelbaum, Grossman and Helpman 2011; Nayak 2011). Relatively poor Georgia is therefore exceptional in exporting wine at an average price equal to or slightly above that for the world as a whole over the past five years.

A further set of influence on comparative advantage that can be important at certain times relates to currency exchange rate movements. A macroeconomic shock such as Argentina's devaluation by two-thirds in late 2001, or a doubling in the Australian-US dollar exchange rate over the past decade due largely to Australia's mining boom, have had major (and opposite) impacts on the international competiveness of wineries in those two Southern Hemisphere countries.

For Georgia, terroir and tradition have been the key domestic influences on its comparative advantage in wine production. Even so, there was some importation of exotic technologies and varieties from Western Europe in the $19^{\text {th }}$ century, and has been again following independence in 1991.

The international competitiveness of its wineries also has been heavily influenced by its long-established trade relations with Russia. Somewhat in contrast to the nineteenth century's bilateral trade experience, during the Soviet era the choice of both technologies and grape varieties in Georgia was focused on Russian demands for maximum quantities of semi- 
sweet, low-quality, mostly red wines (Kharbedia 2010). With the dissolution of the Soviet Union and even more so Russia's ban on imports of Georgian wine since 2006, the country now has a large degree of freedom to influence its future comparative advantage in wine.

To meet the Minister of Agriculture’s goal of trebling wine exports by 2015, there would need to be not just a one-quarter increase in total winegrape production but a neartrebling in commercial bottled wine output. To examine what will be needed to meet that export goal in a sustainable way, it is helpful to review where Georgia is currently relative to other wine-exporting countries and especially those that have enjoyed rapid export growth over the past decade or two.

\subsection{Georgia's wine comparative advantage}

Trade data of the past decade reveal that Georgia's strong comparative advantage in wine is second only to Moldova. The indicator shown in Table 1 is wine's share of national merchandise exports relative to its share of global exports. However, the high value for Georgia has slipped a lot since the Russian import embargo, while those of several other countries (most notably New Zealand and Argentina) have risen a lot during the past decade. That is also reflected in the share of Georgia's wine production volume (including noncommercial supplies) that is exported: it grew rapidly over the first half of the past decade to nearly 50 percent, but then fell sharply with the Russian ban and has yet to return to its 199599 average of 14 percent (Figure 2).

The country's wine comparative advantage is driven in large part by having ample terroir for winegrapes, and by having got to know that terroir very well through utilizing it for millennia. Unlike elsewhere in the former Soviet Union, Georgia's vineyards were not decimated following the Union breakup: between 1992 and 1998 its wine production fell just 16 percent, compared with almost 60 percent for Russia and Moldova (Noev and Swinnen 2004). One quick way of guessing the potential for expanding further is to look at the share of agricultural crop land under vines. As of 2009, Georgia was ranked fourth in the world at 8 percent, after Portugal, Chile and Italy and ahead of Moldova and Spain at 6 percent and Macedonia and France at 4 percent - and far ahead of the New World exporters at just 0.3 percent (Figure 3). Thus Georgia’s potential for vineyard expansion may be not very great. True, Georgia's vineyard area was 2.5 times greater at its peak just before the Soviet antialcohol push in the mid-1980s to remove vines, but the quality of many of those vineyards was low. 
Leaving aside the Russian market, Georgia is a relative latecomer to the tidal wave of wine export growth that has accompanied the past two decades of globalization. One symptom of that is the rise in the share of wine exported by both Western Europe and the New World. The share of European Union wine that is exported has risen from one-sixth to more than one-third since the late 1980s. Far more dramatic, however, is the rise in that share for the New World, from just 2 percent to almost 40 percent (Anderson 2004). Hence onethird of the world's wine is now consumed outside its country of production, while Georgia's share is less than one-eighth and much lower than for most of its East European wineproducing neighbors (Figure 4).

Being a latecomer to Western markets can have some benefits, in addition to wellknown challenges. Recent history shows that it has been possible for several New World countries simultaneously to enjoy rapid growth in wine exports (Figure 5), and from very low bases in most cases (Figure 6). In Argentina's case, the value of their wine exports (in current US dollars) has grown at more than 20 percent per year since 2001, and New Zealand's at 25 percent, following Australia's 19 percent per year growth during the 1990s (Anderson and Nelgen 2011, Tables 63 and 127). Those experiences suggest that it would be technically possible for Georgia to rapidly expand its exports, if enough other supportive conditions are in place (see Section 4 below).

The recent New World history also reveals that output expansion is not the only way to achieve export growth. The export growth in Argentina, Chile and South Africa, for example, was possible without greatly expanding production initially. This is because it was accompanied by stagnant or falling domestic demand for wine. In New Zealand, production switched from low-quality wine for domestic consumers to high-quality wine mostly for export, while local demand was met largely by a doubling over the past decade in wine imports. As for Australia, its export surge in the 1990s was preceded by a period of gradual decline in production which meant there was idle capacity ready and waiting to be utilized when the Australian dollar fell in value in the mid-1980s -- as was also the case for Argentina following its devaluation in late 2001.

Georgia may well be in a somewhat comparable position now to that which Australia was in the mid-1980s and Argentina was in 2001, in the sense that both vineyards and winery capacity have been underutilized in Georgia since the imposition in 2006 of the Russian trade embargo.

Nor has Georgia’s wine industry come under as much domestic competitive pressure from an export boom in other parts of its economy as has occurred in Central and East 
European economies. Georgia is more like Hungary and Bulgaria in having a small share of its wine production exported, rather than like Moldova and Macedonia where export sales dominate domestic sales (Figure 7), except that it currently has a much higher average price for its exports. The unit value of Georgia’s wine exports in 2009, at US\$3.33 per litre, was above the global average of \$2.92 and within 4 cents of the EU15 average. While that is not as high as those of France or New Zealand, it is among the highest in the world and well above those of other New World exporters and transition economies (Figure 8). It is also far above Georgia’s earlier averages of \$1.05 and \$1.92 per litre in 1995-99 and 2000-05, respectively (Figure 1). Georgia’s bottled still wine export price is only slightly higher (since Georgia normally has exported very little in bulk), but if inflated by the global average 8.3 percent to allow for freight (the gap between fob and cif prices) it amounts to an average import price at destination of \$3.96 in 2009. That is very close to that year’s global average unit value of bottled still wine imports of $\$ 4.05$ per litre. However, that world average is dominated by the large low-priced UK and German markets: most other significant importing countries have an average import price for bottled still wine well above \$4 per litre.

We turn now to the core questions of whether/how Georgia can build on its present position to become a significantly greater exporter of wine (Section 4), and what that would do to boost the country’s rural development and poverty alleviation (final Section 5).

\section{What is needed to realize Georgia's full potential as a wine exporter?}

Georgia has many natural advantages that could be further exploited in marketing its wine abroad. It has, for example:

- a history of 8000 vintages, longer than any other country;

- more than 500 unique Vitis vinifera winegrape varietals;

- a wide diversity of terroirs in which winegrapes can thrive;

- a unique and ancient organic production method (qvevri), possibly to be nominated for UNESCO cultural heritage protection in 2012;

- low-cost labor and viticultural land by Western standards;

- low chemical and water applications even in its more-modern styles of production;

- a unique and authentic food/wine/hospitality culture; 
- a reputation (especially in Russia and among diaspora elsewhere) for approachable semi-sweet red wine and for high-quality brandy and chacha (grappa); and

- beautiful mountain-backed landscapes and stunning historical architecture at the eastern edge of Europe to add to the attractions for food-and-wine tourists.

While those advantages on their own are not enough to guarantee sales in new markets, ${ }^{2}$ they can certainly be used to capture the initial attention of foreign wine writers, importers and consumers via a generic 'Wine of Georgia' marketing campaign. The advantage of still having the ancient qvevri production style, for example, is a genuine point of difference (as highlighted in the DVDs by Kokochasvili 2011 and Lambert and Finlay 2011) even if the shares of qvevri wine in Georgia's labelled wine production and exports remain small.

A pre-requisite for launching a major generic or brand marketing campaign is to have products ready in sufficient volume to be able to be well-positioned in clearly defined market segments. In their Export Market Development Action Plan, the Georgian Wine Association (GWA 2011) has identified at least three broad quality segments in foreign markets for dry light still wine:

- non-premium wine, typically sold in bulk;

- popular premium wine that newcomer consumers often find attractive, mostly retailed in bottles (or bag-in-box, but increasingly over recent years New World wineries have exported in bulk before they or a supermarket bottle it in its destination country); and

- $\quad$ super-premium or fine wine, always exported in bottles.

According to Anderson and Nelgen (2011, Tables 158, 169 and 170), these three segments in 2009 accounted for 37, 50 and 7 percent of the volume of global wine imports, respectively (with sparkling wine making up the remaining 6 percent), and for 11, 58 and 16 percent of the value of global wine imports, respectively (plus sparkling wine for the remaining 15 percent). The average export unit values per litre thus escalate across that range, from around US\$0.90 for non-premium in 2009 to $\$ 3.25$ for commercial premium, $\$ 6.50$ for superpremium and \$8.10 for sparkling wine (or \$4.45 if French Champagne is excluded). The challenge for Georgian winemakers is to be cost competitive in supplying into one or more of those market segments - and at something less than those average prices, so as to entice newcomers to try their wine.

\footnotetext{
${ }^{2}$ Italy, for example, has had more than 2000 vintages, has 227 'main’ winegrape varieties grown in a wide range of terroirs in very attractive settings, and is well-known globally and appreciated for its food-and-wine culture.
} 


\subsection{Which market segments, which destinations to target, which varieties to focus on?}

Since Georgia already has a strong reputation in Russia, other CIS countries and among exSoviet diaspora for its semi-sweet red wine and for its brandy and chacha, it will be able to build on that in non-CIS countries, beginning in cities/areas where the diaspora have congregated. It will also be able to quickly return to the Russian market when that re-opens, should wineries so choose - although that market is slowly changing as it gets exposed to wines from non-CIS countries (Scholes 2011). What is, or could be, Georgia's comparative advantages in the above three dry still wine segments outside of Russia, and therefore which countries should its wineries target?

The Georgian Wine Association has identified six markets it believes are worth targeting initially. Apart from the smallest of them (Poland), they are listed in Table 2. They comprise the world's three largest wine importers (the UK, the US and Germany) plus Ukraine and China. Around half of the import volume of Germany and China is nonpremium (as is also the case for Russia), compared with just one-quarter for the other three. However, the average price of Georgian exports is a little above the average of the commercial premium category, and Table 2(b) suggests that finer wine segment ('super premium') comprises a very small share of each of those markets - less than 5 percent - apart from the US where it was 8 percent by volume and 18 percent by value in 2009 .

There are marked differences between Western markets. The Georgian Wine Association's Development Action Plan (GWA 2011) recognizes this, and suggests the price points, varieties and styles of Georgian wines that might best be targeted in each market. It suggests aiming for the low end of super-premium sales in all six countries, plus the diaspora market in the US and Germany. It recognizes also the large size of the non-premium market for bulk wine sales in China and Germany, presumably as a way of disposing of (unplanned?) low-quality wine. But it also suggests sales of commercial premium wines in China, Poland and Ukraine, perhaps as a way of dealing with planned super-premium wine that did not quite reach that standard following difficult vintages.

Deloitte Consulting (2011), like many others, point out that the non-premium market is chronically over-supplied globally and that the commercial premium segment has become extremely competitive with very low margins thanks to the supermarket revolution on the buyer side and, on the seller side of the market, the economies of large scale that are possible in commodity wine production in the relatively lightly populated New World. Differentiated 
products, by contrast, not only enjoy higher margins but are more recession-proof (see Gopinath, Itskhoki and Neiman 2011).

As for varieties, Georgia has been blessed with more than 500 indigenous varieties, of which more than half are currently still in production and others are in nurseries. In addition, Georgia imported western winegrape varieties and production and processing technologies as long ago as the 1820s (Kharbedia 2010, p. 33), and more have been planted over the past decade or so. Many of the indigenous varieties have names that western consumers would struggle to remember, and have flavor profiles that may be either insufficiently or too different from those of international varieties to be easily marketable. Even the key indigenous varieties considered most likely to succeed abroad, such as red Saperavi and white Rkatsiteli, are produced in styles that Western consumers may find not immediately approachable. Some wineries are therefore modifying the styles somewhat, while others are blending those varieties with international varieties. If the latter name is placed first on the label of a 50:50 blend, there is the additional advantage that the foreign consumer may be less hesitant to try it once and more likely to enjoy it enough to remember the label when returning to the wineshop for more of the same (or of the adjacent bottle with only the indigenous variety).

Most New World countries have found that they initially became famous for just one or two varieties - as has Austria since its recent resurgence as a wine exporter. ${ }^{3}$ The head of Austria's generic wine marketing agency warns that it is wiser to market the country rather than its signature varietal, lest the consumer tire of the latter (Carter 2011). Argentina is aware of that risk, but its export success with Malbec has been so phenomenal that for the moment it continues to ride the wave. ${ }^{4}$

How might Georgia first expand its grape and wine outputs for such export markets, and then expand the demand for the final products in time for when they would be ready for shipping? The key challenges are considered in turn below, drawing where appropriate on the

\footnotetext{
${ }^{3}$ This shows up in varietal intensity indexes, defined as the share of plantings to a variety in a country relative to its share globally. In 2000 Australia's Shiraz index was 9 (and Australia accounted for $4 \%$ of global planting of Shiraz), Argentina's Malbec index was 14 (6\% of global planting), New Zealand's Savignon blanc was 19 (4\% of global planting), and Austria’s Grüner Veltliner was 81 (9\% of global planting - see Anderson 2010).

${ }^{4}$ In 2010, Argentina exported more than 4 million cases of Malbec to the United States, 20 times the amount it sent in 2002 and nearly double its 2008 volume. Malbec, which now represents 60 percent of Argentina's exports to the US, was a rustic red with little appeal outside the country prior to the surge in foreign investment following its devaluation by three-quarters at the end of 2001. However, the style has been transformed over the past decade to broaden hugely its appeal as a food wine even when drunk young. Wines of Argentina, the country's generic marketing agency, is now advancing its message by communicating directly to the consumer with events such as Malbec World Day. Having the cover story of the December 2011 issue of the US magazine Wine Spectator (see Wesley 2011) further boosted their sales in 2012.
} 
experiences of other wine-exporting countries, before also considering the contribution that in-bound wine tourism could make.

\subsection{What is needed to expand export supplies?}

While there appears to be under-utilized capacity in Georgia's wineries and vineyards at present, that may be more apparent than real. Old Soviet winemaking equipment was designed for large-scale production of low-quality semi-sweet red wine for the Russian market, and much of it is unsuitable for producing wines of sufficient quality to compete in Western markets. Even qvevri production methods may need to be modified to ensure they meet the demanding health standards of wine-importing countries.

Most small vineyards would require substantial upgrading before they could produce the grapes needed by a modern export-focused winery. For example, denser spacing of vines might be needed to raise grape quality; different varieties or even different clones may be needed before a contract is offered by a winery to a grower; and even then the winery may require a change in vineyard management practices to ensure the grapes suit the style of wine for which they are to be targeted. The fact that so many Georgian farmers are struggling to sell their surplus grapes and yet new wineries are planting their own vineyards is an indication that the current grape output of smallholders is not meeting the needs of exportfocused wineries.

Even more importantly, there is an evident shortage of skilled viticulturalists, winemakers, and especially wine marketers capable of working together with grapegrowers. Yet that collaboration is essential if small growers are to deliver winegrapes than can lead to a saleable product on time and at the right price point in prospective markets abroad. On top of that, the irrigation infrastructure also needs major improvements if it is to support production in dry years.

The fact that more investment is needed if Georgia's exportable surplus of wine is to expand substantially is similar to the situation faced by all the New World countries that chose to rapidly expand their wine exports over the past decade or two. In Australia's case, the industry attracted the required investment funds by developing a shared 30-year vision for the industry's future called Strategy 2025 (AWF 1995). At the time the targets in that document were considered by many observers as rather optimistic, since they involved a three-fold increase in the real value of wine production, 55 per cent of it for the export market. Yet so convincing was that document, and so intense and rapid was the subsequent 
investment, that the industry was more than half-way towards most of its 30-year targets in just six vintages (leading to excessive production in the subsequent decade - see Anderson 2011).

Investment funds are required for altering or upgrading existing vineyards or planting new ones. They are needed even more immediately than for the building or upgrading wineries, bearing in mind that it takes a few years before grapes from new vineyards are available for producing the desired wine. Funds are needed also to finance the non-trivial costs of planning and then executing a marketing program for those wines. Those funds are required prior to, as well as when, the wines become ready to export to new markets.

In addition to finance for those investment needs of private firms, funds are required at an industry level for investing in collective goods and services. These include targeted viticultural, winemaking and wine marketing education plus extension and leadership skills development, grape and wine research and development (R\&D), generic promotion of 'Wines of Georgia' (see next sub-section), and more statistical data collection and up-to-date dissemination. Data are especially needed on the pace and nature of expansion in vineyard and winery capacity, as an aid to investors and so as to avoid the excessive exuberance in expanding that Australia experienced in the ten years following the release of its 30-year plan, which contributed to the subsequent decline in its average export price (see Figure 9(a)).

It would be a mistake to assume that an expansion of grape and wine R\&D investment is something that Georgia can postpone. This is despite the fact that its traditional production methods are well know, having been passed down through the generations, and that the published results of the many research institutes abroad concerning alternative production methods can be readily accessed via the internet. The reason is that, apart from the qvevri method, there is almost no such thing as natural wine. On the contrary, there is great scope to alter styles to suit various markets (Lewin 2010). Since Georgia will target market niches requiring styles different from other suppliers, it needs its own R\&D capability. In addition, there is clear evidence that a strong $R \& D$ base is needed not just for innovation but also to adapt technologies adoptable from abroad (Griffiths, Redding and van Reenen 2004). It is therefore laudable that a new Georgia Wine Institute is being established in Tsinandali, Kakheti (as announced in November 2011 by President Saakashvili).

There are some researchers available locally, but additional ones will need to be recruited from the global pool and/or created by providing scholarships for promising students to undertake post-graduate studies in one or other of the world's major wine universities. There are two important additional benefits from such training: it will build links 
for future international collaboration in R\&D; and it will provide a pool of lecturers for teaching undergraduate grape and wine science courses in Georgian universities.

To fund such R\&D expansion and scholarships, a levy might be required. Most wine firms in Georgia are too small to justify their own R\&D facility. If foreign assistance grants are insufficient, and if the government feels this activity would have too few spillover benefits beyond the wine industry to justify full public funding, then one possibility is to collect a small levy on all exported wine. That levy process could then also be used to help fund the generic promotion proposed in the next sub-section. It could also be used to cover the cost of inspecting a sample of each wine destined for export, to ensure that only wine of sufficient quality is allowed to carry the words 'Made in Georgia' on its label.

Small winegrape growers are unlikely to contribute to exports without having to agree to management disciplines. Currently there are hundreds of thousands of small winegrape growers and only a few dozen export-capable wineries. While those smallholders mostly produce grapes for home-processing for their own consumption and for informal sales to friends, they could expand their sales to wineries if there was a demand. To do so, however, they would need to forego their reluctance to allow the commercial winery to determine the varieties grown, production techniques used, harvest time, sugar content, etc. More than that, they may be required to enter into a formal contract that would further limit their independence and flexibility, and even then there may be considerable uncertainty as to the final price they would receive for their grapes. ${ }^{5}$ To date wineries exporting to new markets have signed up relatively few growers and have instead planted their own vineyards so as to be able to have full control of the winegrape production part of the supply chain. This issue matters from a rural poverty alleviating perspective, but it will also affect the optimal path of institutional innovation.

Experience in the rest of the world provides some guidance as to how the firm structure of the industry might evolve in Georgia. In all the New World wine-exporting countries, the firm structure is very skewed: the largest winery in each of those countries is responsible for between one-fifth and one-third of all domestic sales, and the four largest for about three-fifths of domestic sales and an even larger share of export sales. By contrast, in Western Europe apart from Portugal, the top four firms are responsible for only between 4

\footnotetext{
${ }^{5}$ In California both high-quality and lower-quality winegrapes tend to be subject to contracts, with the former more likely to include provisions regarding the production process while the latter more likely to focus just on product attributes such as sugar content (Goodhue et al. 2003, Goodhue 2011). Contracts are being used increasingly in Europe's transition economies to assist vertical coordination across various agri-food supply chains. See Dries et al. (2009) and Gorton, Dumitrashko and White (2006) for examples from the dairy industry.
} 
and 20 percent of domestic sales (Table 3). The Old World continues to be dominated by a large number of cooperatives, many of which do not penalize low-quality grapegrowers enough to prevent the delivery of fruit that can be used only for non-premium wine or for industrial alcohol - hence the EU's history of wine lakes since the advent of its Common Agricultural Policy in the early 1960s. In particular, many cooperatives do not appear to be able to successfully export super-premium wines. Nor are they able to compete well in the international market, especially against the very large exporting firms of the New World, in supplying large quantities of consistent commercial premium wines for the major chain stores and supermarkets. Cooperatives are therefore not likely to be the answer for engaging more small growers in a wine export drive - not to mention that many Georgian farmers remain wary of returning to any form of collective.

The recent experience of New World wine countries suggests that the firms that survive and thrive as exporters are the larger and more-productive ones. ${ }^{6}$ This is consistent with empirical evidence from the international economics literature for manufacturers in general. That literature also reveals that the most-productive exporters of differentiated (branded) goods tend to be those who segment their markets and upgrade the quality of the products they sell to high-income countries (Bastos and Silva 2010; Flach 2011). These findings suggest small local firms such as Pheasant's Tears may be the exception rather than the norm among successful wine exporters - although in southern hemisphere countries there are some smaller wineries, which have been under family ownership for several generations, that have emerged as successful exporters. ${ }^{7}$

Given also how crucial it is to understand market niches and the distribution system in each country of destination, a rapid expansion of wine exports from Georgia to the West is likely to require attracting foreign investors already very familiar with selling into those markets. This is especially so because such experienced firms also are more likely to be at the technological frontier in viticulture, oenology and wine marketing and to be able to access the substantial upfront finance that is required to plant new vineyards, construct or renovate a winery, and invest abroad in brand development.

In aspiring to expand production, it should be remembered that there is such a thing as expanding too rapidly. As already mentioned in connection with Figure 9(a), Australia’s

\footnotetext{
${ }^{6}$ Another feature of successful exporters is their financial management capability, not only in raising finance for capital expenditures and dealing well with cash flow fluctuations but also hedging against currency volatility. For an analysis of how currency movements affected the competitiveness of winegrowers in various countries during 2007-11, see Anderson and Wittwer (2012).

${ }^{7}$ See, for example, www.australiasfirstfamiliesofwine.com.au
} 
vineyard area and consequent wine production grew so fast from the mid-1990s that marketers simply could not find enough outlets for it all once the wine from new vines became available for sale - especially when the financial crisis hit the United States and the EU after 2007. The subsequent discounting and sales in bulk rather than in branded bottles is reflected in the rapid decline over the past decade in the unit value of Australian exports shown in Figure 9(a). This led to a commensurate drop in grape prices (by more than onethird for Shiraz between 2008 and 2011 vintages). The same happened to New Zealand from 2007: the unit value of its wine exports fell from US\$6.65 in 2007 to \$4.93 in 2010 (Anderson and Nelgen 2011, Table 79), with bulk wine’s share of exports rising from 5 to 30 percent (NZW 2011). One way to reduce the risk of over-supply is to collect and promptly disseminate accurate and comprehensive data on nursery sales, new plantings, vineyard renovations and winery crushing and bottling capacity.

\subsection{How to expand export demand? ${ }^{8}$}

A case can be made for generic promotion to accompany and support private-sector promotion. Certainly firms are capable of developing their own brands according to their competitive advantages and points of difference but, especially in markets unfamiliar with the country's wines, attention first needs to be drawn to what the nation has to offer in general. Empirical evidence supports this view for products in general, ${ }^{9}$ and it is even more so for credence goods such as wine.

The experiences of other small economies provide guidance as to what generic promotion works well. Chile (www.winesofchile.com) and New Zealand (www.nzwine.com) are good examples. So too is Austria (www.austrianwine.com), a country in which, like Georgia, the majority of winegrape growers have less than 1 hectare of vines. All three countries have sought to associate their wines with their country, and to emphasize the clean, green image of their beautiful vineyards against a background of snow-capped mountains something Georgia can surely emulate.

\footnotetext{
${ }^{8}$ Demand for Georgian wines in the CIS countries is already well established, so attention in this section is focused on promoting Georgian wines in non-traditional markets in Western Europe, North America and East Asia.

${ }^{9}$ According to a recent cross-country study by Lederman, Olarreaga and Payton (2009), covering all exports not just wine, a 10 percent increase in the budget for generic export promotion on average leads to between a 0.6 and a 1.0 percent increase in exports. They also find diminishing returns to such expenditures, so the returns are even higher for those countries just beginning to grow their budget for such activities.
} 
Austria provides a lesson on the importance of protecting the generic reputation of a country's wine quality. In 1985, a small proportion of Austrian wine was found to have been adulterated with a harmless but illegal additive to add body and sweetness. Austrian wine exports plummeted by four-fifths within a year, and took more than a decade to recover. That recovery process has been characterized by raising the quality as well as image of Austria's exports (Carter 2011). As a consequence, during the past decade the unit value of those exports has nearly trebled (Figure 9(b)). This underscores the importance of Georgia having in place sound procedures for testing the quality before approving the export of wines labeled 'Made in Georgia'.

New Zealand has done well in promoting images of its countryside even though most of its customers in the northern hemisphere have not visited such a distant place. That is good news for Georgia because, even though it is on the edge of Europe, to those living near the north Atlantic it is still considered remote (infrequent flights, unfamiliar airlines, troubled borders). If images can substitute for reality, they can buy time for Georgia to build its wine tourism (see next sub-section).

In the first decade of its export boom, Australia’s generic promotion was considered highly successful. It promoted the idea of 'sunshine in a bottle', of bold up-front fruity styles that appealed very much to newcomers to wine who were the target of supermarkets. But consumers - or at least wine columnists and other opinion leaders - gradually tired of the uniformity of styles. The reputation of Australian wine has gradually slipped over recent years as a consequence. This is ironic, because it occurred just as many Australian winemakers were moving to more elegant, restrained styles to accompany fine foods (Hooke 2011). As with Austria, the lesson is that while it is a slow process to build a strong generic reputation, the dismantling of that reputation can be swift. Australia is now investing heavily in rebuilding its reputation but with a focus on finer wines as well (www.apluswines.com).

Georgia can emphasize numerous points of difference to attract attention to its wines. Those differences, listed at the start of this section, include its wines' history, diversity, uniqueness, and authenticity. Its qvevri technology is especially appealing to wine enthusiasts. It could also appeal to a much wider clientele if it could be demonstrated that qvevri wine is healthier than wine as conventionally produced in the west. There is already some preliminary scientific evidence to support that claim (Shalashvili et al. 2010; Diaz 2011). If such studies were to be replicated and supplemented by other scientists, particularly in the countries which are to be targeted as export markets, they could be drawn on by wine writers in their reviews of Georgian wines. Meanwhile, some producers in Italy and Germany 
have been experimenting with the qvevri technology (Newsweek, 31 Oct 2011, pp.50-51).

Rather than being concerned about this development, it should be encouraged: imitation is the best of compliments and, as with that coverage in Newsweek, it can generate additional - and free - publicity for Georgia.

Georgia’s generic promotion initially should be country-wide rather than also stressing specific regions. However, just as the Marlborough region now had until recently 75 percent of New Zealand's winegrape area (currently 66 percent), so Kakheti has a similarly high proportion in Georgia. Hence that region will tend to become the best known, especially if it continues to also be the region where wine tourism is developing fastest. It is thus helpful that in 2011 the European Union agreed to legally protect Georgia's geographical appellations. Other countries importing Georgian wine will now be able to be encouraged to follow suit. This is particularly important in countries where there is a risk of counterfeit wine, as it provides not only recognition but also legal protection.

A single industry body could undertake generic promotion as well as administer generic R\&D funds. Experience in New World countries suggests there are economies of size for a small country to combine the roles of promotion, $R \& D$ and regulatory oversight in one industry-owned organization, as in New Zealand (NZW 2011, p. 21) and probably also in Australia by the end of 2013 (WFA 2012). That allows the returns from those three activities can be compared and the budget divided so as to maximize its overall return to the industry (and to the government, if it also is a financial stakeholder).

The budget for generic promotion and R\&D should be in the millions of dollars. Australia and New Zealand each spend close to 1 US cent/litre of wine produced on generic promotion (and associated regulatory functions), while Bordeaux spends more than 3 cents. Australia spends about 2 cents/litre on R\&D, compared with about 1 cent in New Zealand. So if Georgia were to emulate Australia’s spending pattern, with its annual production near 100ML per year that would suggest an annual budget of \$1million/year on generic promotion and \$2million/year on R\&D and related extension activities initially (and to grow in parallel with the industry's output). Even if one were to exclude non-commercial production for the home market from the base of the calculus, about half those budgets would be required by 2015 if the President's aim of trebling the volume of exports between 2011 and 2015 is realized.

\subsection{What role for wine tourism?}


The potential to build wine tourism in Georgia is enormous, as eloquently explained by Taber (2009). A start has been made, with some wineries offering cellar-door tastings, but many other components need to be added. They include more hotels ranging up to 4- if not 5-star (with internet access, brewed coffee and dependable hot water), similar-quality restaurants with English-language waiters who know how to serve wine with food (with some at least offering a supra experience), more sealed roads connecting key sites, better road signage with a wine route symbol, information bays/kiosks, wine route maps and booklets in English and other key languages (with sample itineraries and contact details and opening times of each winery's cellar door and each major restaurant), acceptance of major credit cards, and comprehensive multilingual websites to facilitate pre-tour planning. Recently two excellent DVDs have been produced to explain the uniqueness of what Georgia has to offer (Kokochasvili 2011, Lambert and Finlay 2011). If they are circulated widely, through being given to opinion-shaping visitors to take home and share with friends and colleagues, a better understanding of what Georgia has to offer can spread much faster than just via word of mouth.

To minimize travel times between venues, a clustering of cellar doors would help greatly. This is especially so if the cluster included or was nearby accommodation and dining and also near historic sites such as Tsinandali Estate or Alaverdi Monastery. ${ }^{10}$ Given the heavy concentration of wine production in Kakheti, it would make sense to concentrate public infrastructure expansion in that area initially.

Investment finance is needed to build the infrastructure and facilities expected by today's international tourists from high-income countries, and then the construction phase can employ many low-skilled workers. This will thereby provide a major expansion in part-time off-farm earnings for farm households.

Once built, wineries, cellar door outlets, restaurants and hotels also require, on an ongoing basis, large numbers of employees over the full spectrum of skills. To build those skills, post-secondary school training opportunities need to be created, such as in hospitality, vineyard management, winery tasks and cellar door skills. Then wine tourism could be a major supplement to the employment- and income-creating opportunities that will be provided by expanding grape and wine production in Georgia.

\footnotetext{
${ }^{10}$ For more-detailed suggestions from a visiting group of opinion-shapers, see Deloitte Consulting (2011).
} 


\section{Implications for policy and poverty alleviation}

The above makes clear that the potential for wine export and in-bound wine tourism growth in Georgia is very real but also that there are many challenges to be faced. That is true regardless of whether/when Russia lifts its embargo on wine imports from Georgia because, since that embargo was introduced in 2006, Russia has been importing from an expanding set of western countries and for a wider range of types and qualities of wine as that market becomes more sophisticated and westernized.

To realize Georgia's wine export potential, inputs are required not only from the private sector but also from the government, beginning with the national investment agency. That agency, Invest in Georgia, has a role in attracting investor interest in the industry and in associated tourism opportunities. In conjunction with the Georgian Wine Association's Development Action Plan (GWA 2011), Invest in Georgia can build awareness among prospective investors both domestically and abroad. The diaspora is an obvious target group, but so too are the large wine corporations that are already well established in the target markets.

The Georgian National Tourism Agency clearly also has a major role to play in developing in-bound tourism. The food-and-wine focus provides a major hook though, so the industry needs to work with the Tourism Agency to reap mutual benefits. This linkage between the promotion of Georgian wine and Georgia as a tourist destination makes a strong economic case for government co-funding of wine promotion in selected markets abroad.

The government also has a key role in supporting investments in grape and wine $\mathrm{R} \& \mathrm{D}$, in the tertiary education of viticulturalists, oenologists and wine marketers, and in the post-secondary-school training of workers for the industry and for the wine tourism sector. A strong economic case can be made for government co-funding of agricultural research in general, without which there inevitably will be under-investment because the private sector is unable to capture all of society’s gains from such investments (Alston and Fulton 2012). The case is even stronger for grape and wine research in Georgia, given the contribution it could make to expand dramatically the revenue from the low-performing grapevines of many lowincome farm households (and even to encourage the re-planting of vineyards that were pulled out from the mid-1980s).

If the industry is to be able to continue to produce even in dry seasons, it needs reliable access to irrigation. Currently the irrigation infrastructure in Georgia is very run down. Getting the right institutions and policies in place for that to happen in a major 
challenge (see, e.g., Young 2010), but it will have a high social payoff as it would help not only the wine industry but also horticultural producers. Since that industry is very laborintensive, that would add to the expansion of jobs in rural areas. If it too became more exportfocused, the jobs would include packing, processing and transport activities. As such countries as Chile and Peru have found over the past two decades, this can provide a great boost to rural development and to the alleviation of poverty.

Finally, the Government need to reform its current program of requiring commercial wineries to pay growers a high minimum winegrape price, and competing with them by also buying grapes (often early in the season) and processing them in a purpose-built state-owned winery (Gruzvinprom) for eventually exporting low-priced wine in bulk or bottles, or converting the surplus to industrial alcohol), thereby undermining the private sector's efforts to develop premium markets abroad. ${ }^{11}$ Apart from the fiscal wastage of such a program (since costs are likely to exceed sales revenue of the state-owned winery), it provides a disincentive for below-average growers to raise the quality of their product to a level acceptable to commercial wineries. If the resulting accumulation of low-quality wine is then exported in bulk to neighboring countries, there is the risk that it will be bottled and sold as Wine of Georgia (as has apparently already happened in Ukraine), and thus diminish the reputation of bottled wine exported directly by Georgia's commercial wineries. Instead of grape price supports, that fiscal expenditure could be used to directly support poor farm families via conditional cash e-transfers either to upgrade their winegrape production or to restructure away from grape growing and towards more profitable activities.

\section{References}

Alston, J.M. and M. Fulton (2012), 'Sources of Institutional Failure and Underinvestment in Levy-Funded Agricultural Research', Invited paper for the $56^{\text {th }}$ AARES Annual Conference, Fremantle, Western Australia, 8-10 February.

Anderson, K. (ed.) (2004), The World's Wine Markets: Globalization at Work, Cheltenham UK: Edward Elgar.

Anderson, K. (2010), 'Varietal Intensities and Similarities of the World’s Wine Regions', Journal of Wine Economics 5(2): 270-309, Winter.

\footnotetext{
${ }^{11}$ The Government also announced in 2011 that it would invest in the reconstruction of a glass bottle factory, crowding out a planned private investment to expand another glass bottle manufacturer owned by a Turkish firm.
} 
Anderson, K. (2011), 'Contributions of the Innovation System to Australia’s Wine Industry Growth', Ch. 4 in E. Giuliana, A. Morrison and R. Rabellotti (eds.), Innovation and Technological Catch-up: The Changing Geography of Wine Production, Cheltenham UK: Edward Elgar.

Anderson, K. and S. Nelgen (2011), Global Wine Markets, 1961 to 2009: A Statistical Compendium, Adelaide: University of Adelaide Press, accessible as an e-book at www.adelaide.edu.au/press/titles/global-wine and as Excel spreadsheets at www.adelaide.edu.au/wine-econ/databases/GWM/

Anderson, K. and G. Wittwer (2011), 'Modelling the Impact of Exchange Rate Movements on the World's Wine Markets, 2007-2011', Working Paper 0312, Wine Economics Research Centre, University of Adelaide, November. www.adelaide.edu.au/wineecon/pubs/working_papers/

AWF (1995), Strategy 2025: The Australian Wine Industry, Adelaide: Winemakers’ Federation of Australia for the Australian Wine Foundation.

Bastos, P. and Silva, J. (2010), ‘The Quality of a Firm’s Exports: Where You Export to Matters', Journal of International Economics 82(2): 99-111, November.

Carter, F. (2011), ‘Austrian Maverick: An Interview with Willi Klinger’, Meininger's Wine Business International 6(5): 30-33, October.

Cross, R., A.J. Plantinga and R.N. Stavins (2011), 'The Value of Terroir: Hedonic Estimation of Vineyard Sale Prices', Journal of Wine Economics 6(1): 1-14.

Deloitte Consulting (2011), ‘Wine Opinion-Shapers’ Visit to Georgia: Compilation of Trip Reports’, Tbilisi: USAID Georgia, November.

Diaz, C. (2011), 'Studies of Traditional Winemaking Methods Based on Spontaneous Fermentation', Paper presented at the $1^{\text {st }}$ Qvevri Wine Symposium, Georgia, 15-18 September.

Dries, L., E. Germenji, N. Noev and J.F.M. Swinnen (2009), 'Farmers, Vertical Coordination, and the Restructuring of Dairy Supply Chains in Central and Eastern Europe', World Development 37(11): 1742-58.

Fajgelbaum, P., G.M. Grossman and E. Helpman (2011), 'Income Distribution, Product Quality and International Trade’, Journal of Political Economy 119(4): 721-65, August.

Flach, L. (2011), ‘Quality Upgrading and Price Heterogeneity: Evidence from Brazilian Manufacturing Exporters', paper presented to the $10^{\text {th }}$ Annual Postgraduate 
Conference, University of Nottingham, 14-15 April. www.nottingham.ac.uk/gep/newsevents/conferences/2011/postgrad-conf-14-04-11.aspx

Friberg, R., R.W. Paterson and A.D. Richardson (2011), 'Why is there a Home Bias: A Case Study of Wine', Journal of Wine Economics 6(1): 37-66.

Gerguad, O. and V. Ginsburg (2008), 'Natural Endowments, Production Technologies and the Quality of Wines in Bordeaux: Does Terroir Matter?’ Economic Journal 118(529): F142-57, June. Reprinted in Journal of Wine Economics 5(1): 3-21, 2010.

Giuliana, E., A. Morrison and R. Rabellotti (eds.) (2011), Innovation and Technological Catch-up: The Changing Geography of Wine Production, Cheltenham UK: Edward Elgar.

Gladstones, J. (1992), Viticulture and Environment, Adelaide: Winetitles.

Goodhue, R.E. (2011), ‘Food Quality: The Design of Incentive Contracts’, Annual Review of Resource Economics 3: 119-40.

Goodhue, R.E., D.M. Heien, H. Lee and D.A. Sumner (2003), 'Contracts and Quality in the California Winegrape industry', Review of Industrial Organization 23(3-4): 267-82, December.

Gopinath, G., O. Itskhoki and B. Neiman (2011), 'Trade Prices and the Global Trade Collapse of 2008-2009', NBER Working Paper 17594, Cambridge MA, November.

Gorton, M., M. Dumitrashko and J. White (2006), 'Overcoming Supply Chain Failure in the Agri-food Sector: A Case Study from Moldova’, Food Policy 31: 90-103.

Griffiths, R., S. Redding and J. van Reenen (2004), 'Mapping the Two Faces of R\&D: Productivity Growth in a Panel of OECD Industries', Review of Economics and Statistics 86(4): 883-95, December.

GWA (2011), Sector Export Market Development Action Plan (SEMDAP): Wine Sector, Tbilisi: Georgian Wine Association.

Hayami, Y. and V.W. Ruttan (1985), Agricultural Development: An International Perspective, Baltimore MD: Johns Hopkins University Press.

Hooke, H. (2011), 'Australia is the Most Under-Appreciated Wine Country’, Decanter, 27 September.

Kharbedia, M. (2010), Georgia: Cradle of Wine, Tbilisi: Wine Club.

Kokochasvili, M. (2011), The Cradle of Wine [DVD], Tbilisi: Young Directors Union New Studio.

Lambert, D. and J. Finlay (2011), That Crazy French Woman ... in Georgia [DVD], London: That Crazy French Woman Productions. 
Lederman, D., M. Olarreaga and L. Payton (2009), 'Export Promotion Agencies Revisited', Policy Research Working Paper 5125, World Bank, Washington DC, November.

Lewin, B. (2010), Wine Myths and Reality, San Francisco: Wine Appreciation Guild.

McGovern, P. (2003), Ancient Wine: The Search for the Origins of Viticulture, Princeton NJ: Princeton University Press.

McGovern, P. (2009), Uncorking the Past: The Quest for Wine, Beer, and Other Alcoholic Beverages, Berkeley CA: University of California Press.

Nayak, A. (2011), 'Does Variety Fit the Quality Bill? Factor-Endowments Driven Differences in Trade, Export Margins, Prices and Production Techniques’, mimeo, Purdue University, West Lafayette IN, May. www.auburn.edul azn0018

Noev, N. and J.F.M. Swinnen (2004), ‘Eastern Europe and the Former Soviet Union’, Ch. 9 in Anderson, K. (ed.), The World's Wine Markets: Globalization at Work, Cheltenham UK: Edward Elgar.

NSO (2011a), Agriculture of Georgia 2010, Tbilisi: National Statistical Office of Georgia. www.geostat.ge

NSO (2011b), Households' Income and Expenditure 2010, Tbilisi: National Statistical Office of Georgia. www.geostat.ge

NSO (2011c), External Trade of Georgia, Tbilisi: National Statistical Office of Georgia. www.geostat.ge

NZW (2011), New Zealand Winegrowers Strategic Review, Auckland: New Zealand Winegrowers, November.

Scholes, E. (2011), 'Russia’s Emerging Wine Culture’, Meininger's Wine Business International 6(4): 33-35, September.

Shalashvili, A., D. Ugrekhelidze, I. Targamadze, N. Zambakhidze and L. Tsereteli(2010), 'Comparison of Wines of Georgian (Kakhethian) and European Types According to Quantitative Content of Phenolic Compounds and Antiradical Efficiency’, Paper presented to the $33^{\text {rd }}$ OIV World Congress, Tbilisi, 20-27 June.

Taber, G.M. (2009), 'Kakheti, Georgia - the Last Frontier’, Ch. 13 in his In Search of Bacchus: Wanderings in the Wonderful World of Wine Tourism, New York: Scribner. Wesley, N. (2011), ‘Malbec’s Moment: How a Forgotten Red Grape has Revived Argentina and Taken America by Storm', Wine Spectator, 15 December.

WFA (2012), 'Industry Bodies Seek Merger of Statutory Authorities’, Winemakers' Federation of Australia, Adelaide, 21 February. www.wfa.org.au/merger.aspx 
World Bank (2009), Georgia: Agriculture and Rural Enterprise Development, Washington DC: World Bank, December.

World Bank (2011a), Doing Business 2011, Washington DC: World Bank. www.doingbusiness.org/rankings

World Bank (2011b), World Development Indicators, Washington DC: World Bank. http://data.worldbank.org/data-catalog/world-development-indicators

Young, M. (2010), Environmental Effectiveness and Economic Efficiency of Water Use in Agriculture, Paris: OECD. 
Figure 1: Wine export volume, value and average price, Georgia, 1995 to 2011

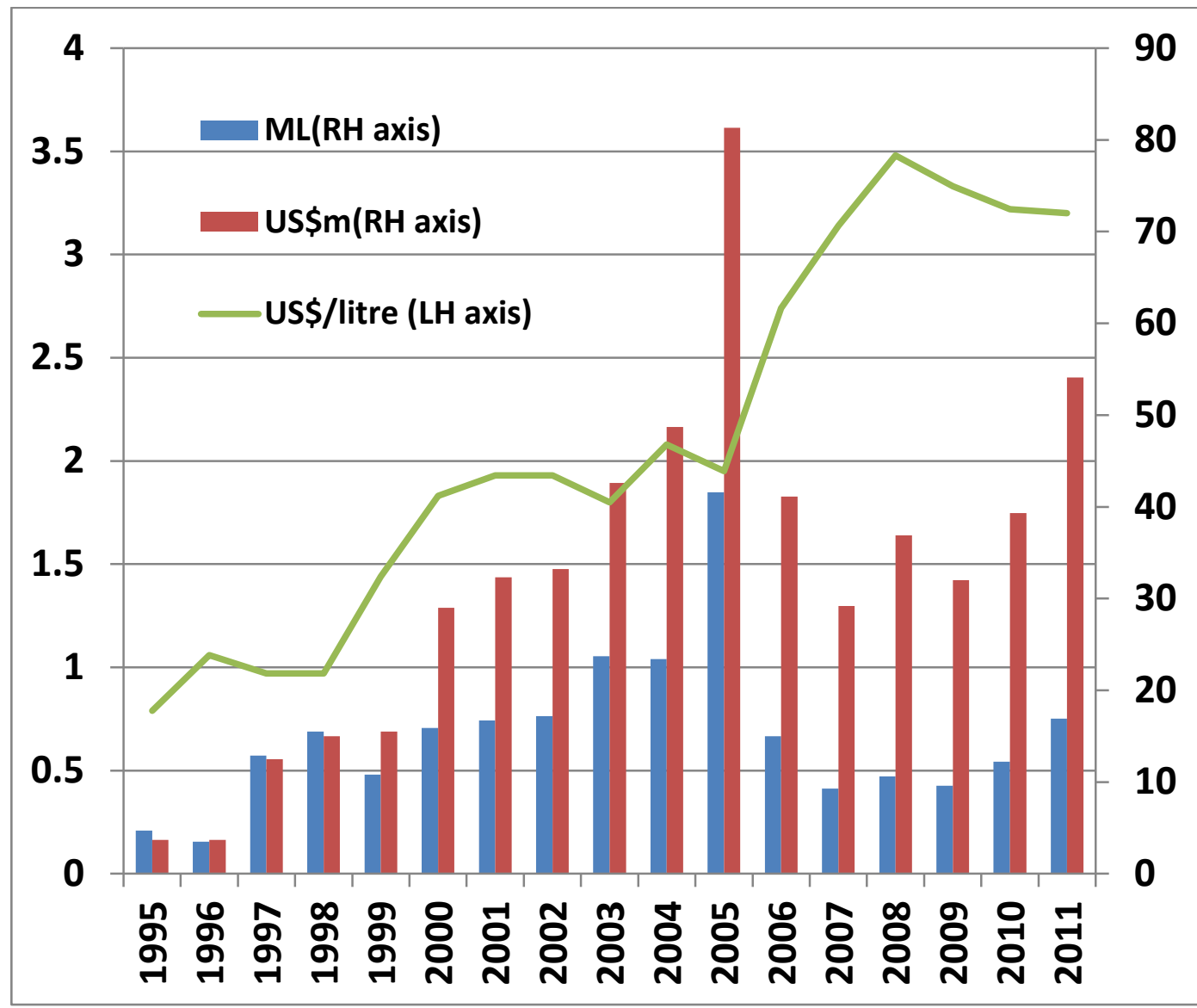

Source: GWA (2011) and Geostat. 
Figure 2: Export share of volume of wine production (including non-commercial), Georgia, 1995 to 2009

(percent)

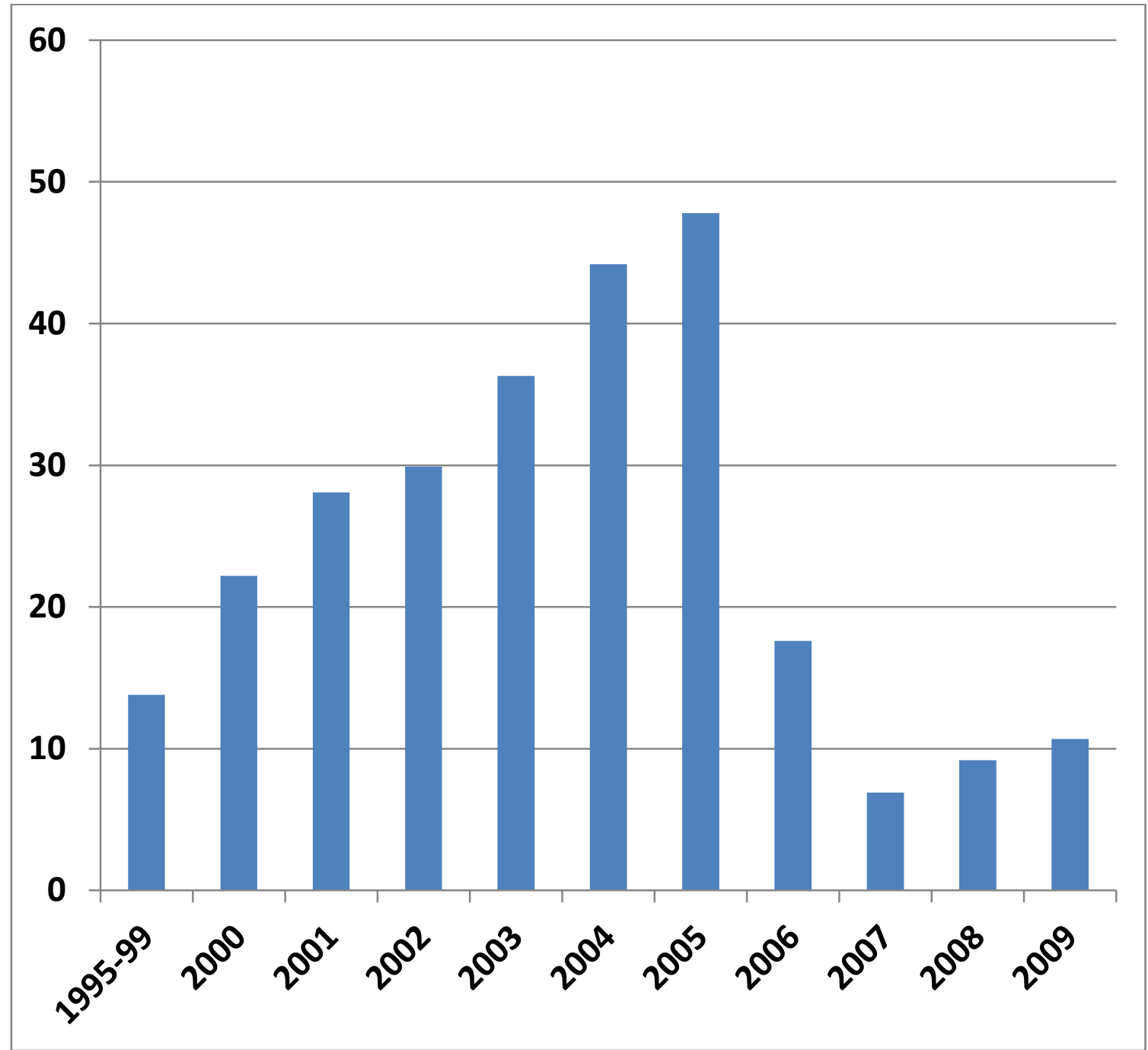

Source: A revision of data in Anderson and Nelgen (2011, Tables 15 and 40), to account for non-commercial production. 
Figure 3: Share of crop land under vines, selected regions, 2009

(percent)

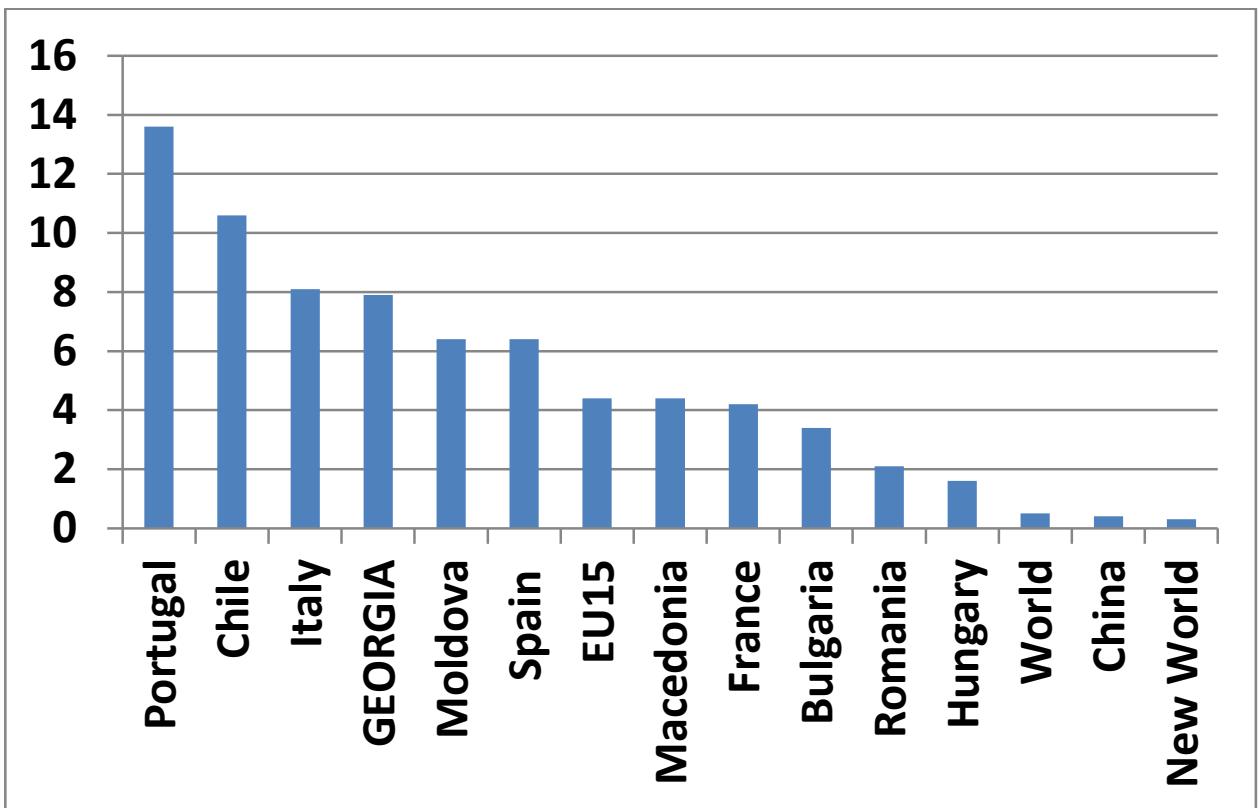

Source: Anderson and Nelgen (2011, Table 6). 
Figure 4: Share of wine production volume exported, selected regions, 2009

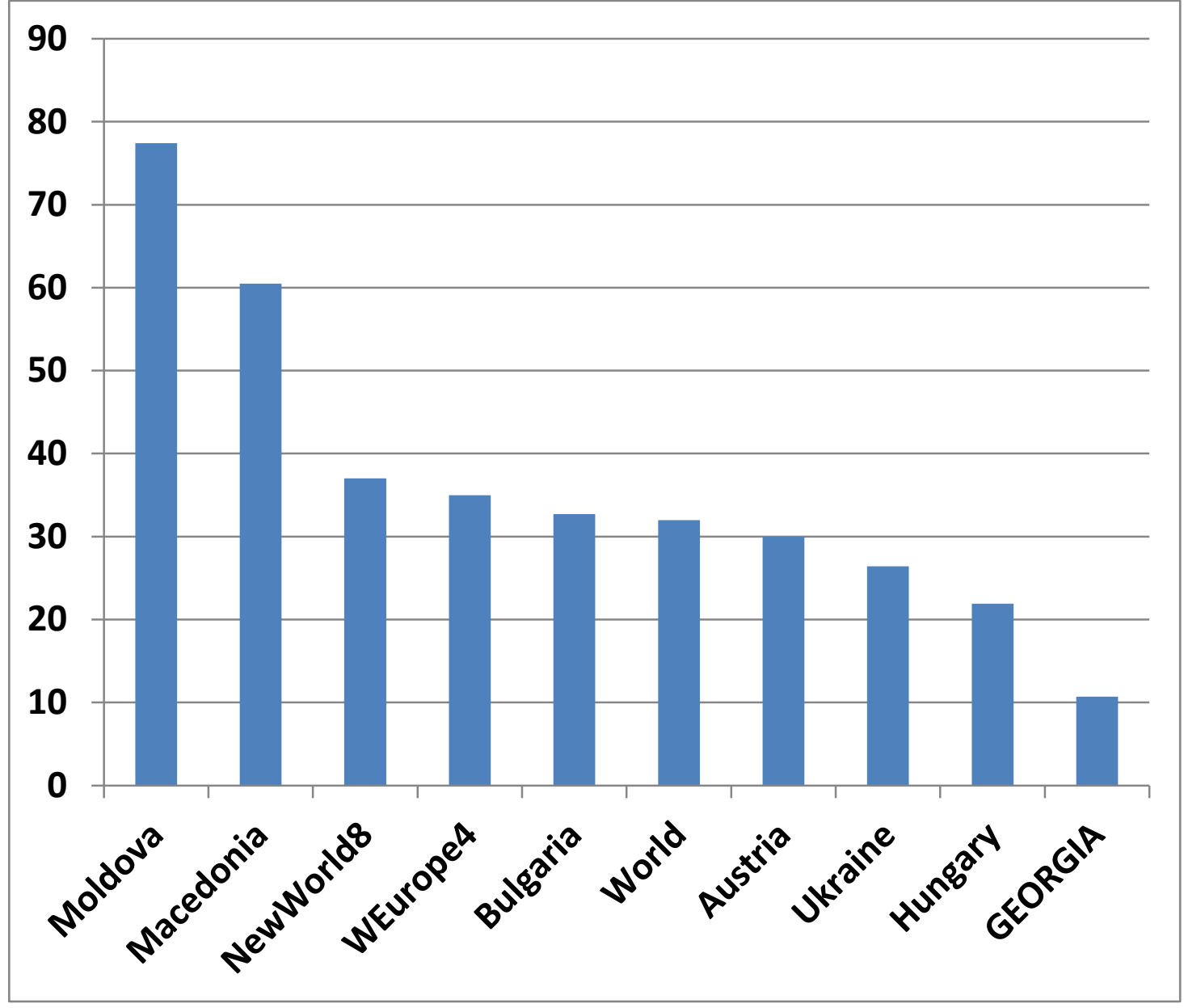

Source: Modified from data in Anderson and Nelgen (2011, Table 51). 
Figure 5: Georgian and New World wine exports, 1995 to 2011

(US\$million)

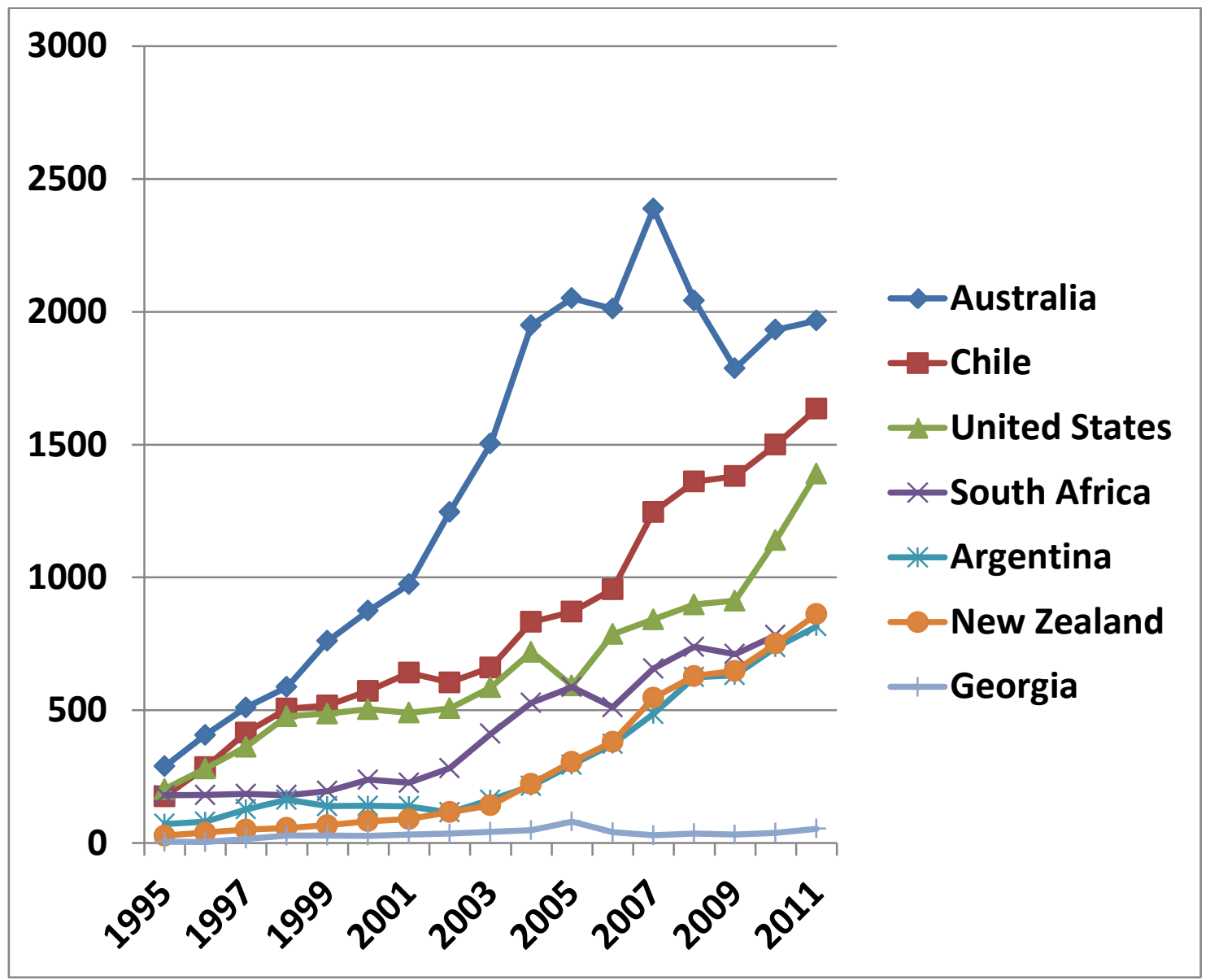

Source: Updated from Anderson and Nelgen (2011, Table 63). 
Figure 6: Share of wine production volume exported, New World countries, 1985-89 and 2007-09

\section{(percent)}

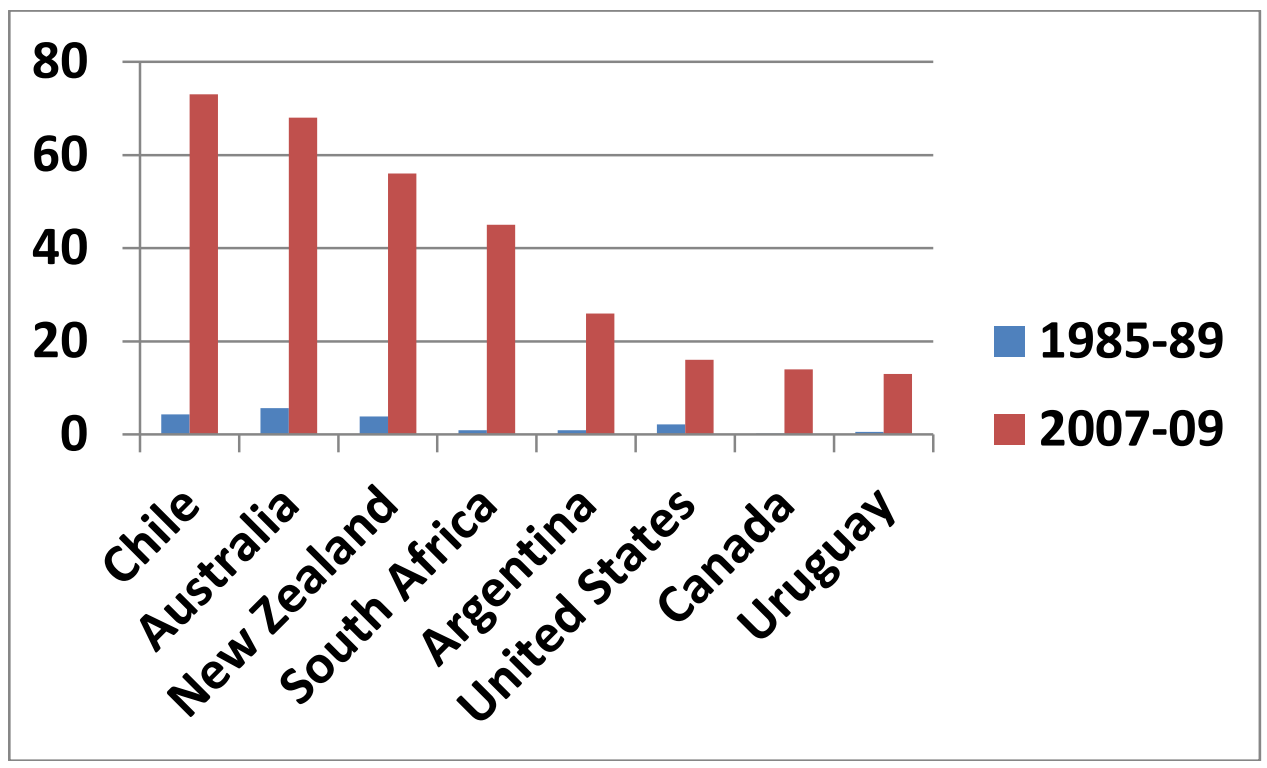

Source: Anderson and Nelgen (2011, Table 79). 
Figure 7: Volume of wine production, consumption (including non-commercial) and exports, Georgia and other transition economies, 2009

(million litres)

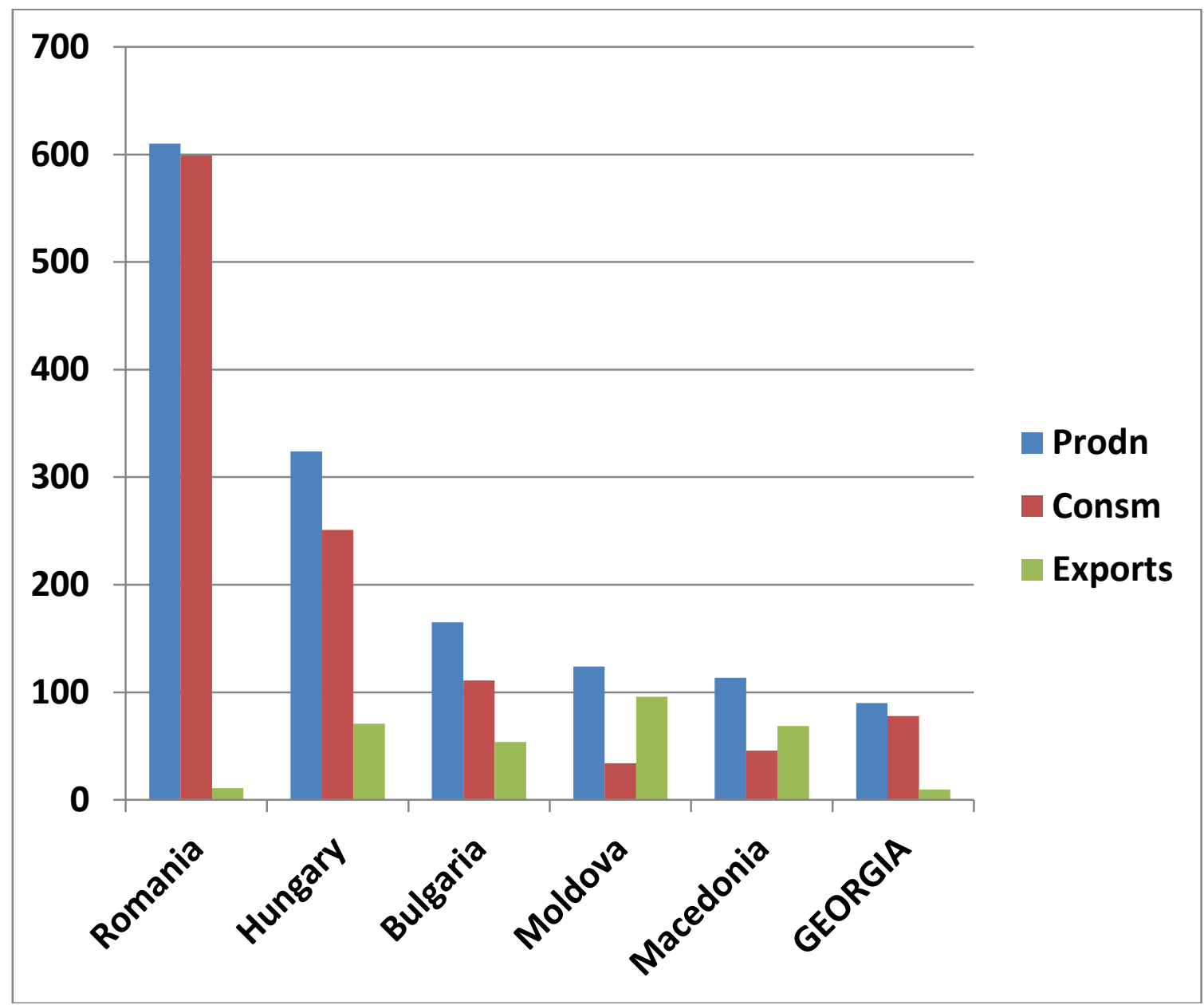

Source: Modified from data in Anderson and Nelgen (2011) to include non-commercial consumption. 
Figure 8: Average price of wine exports, selected countries, 2009

(US\$/litre)

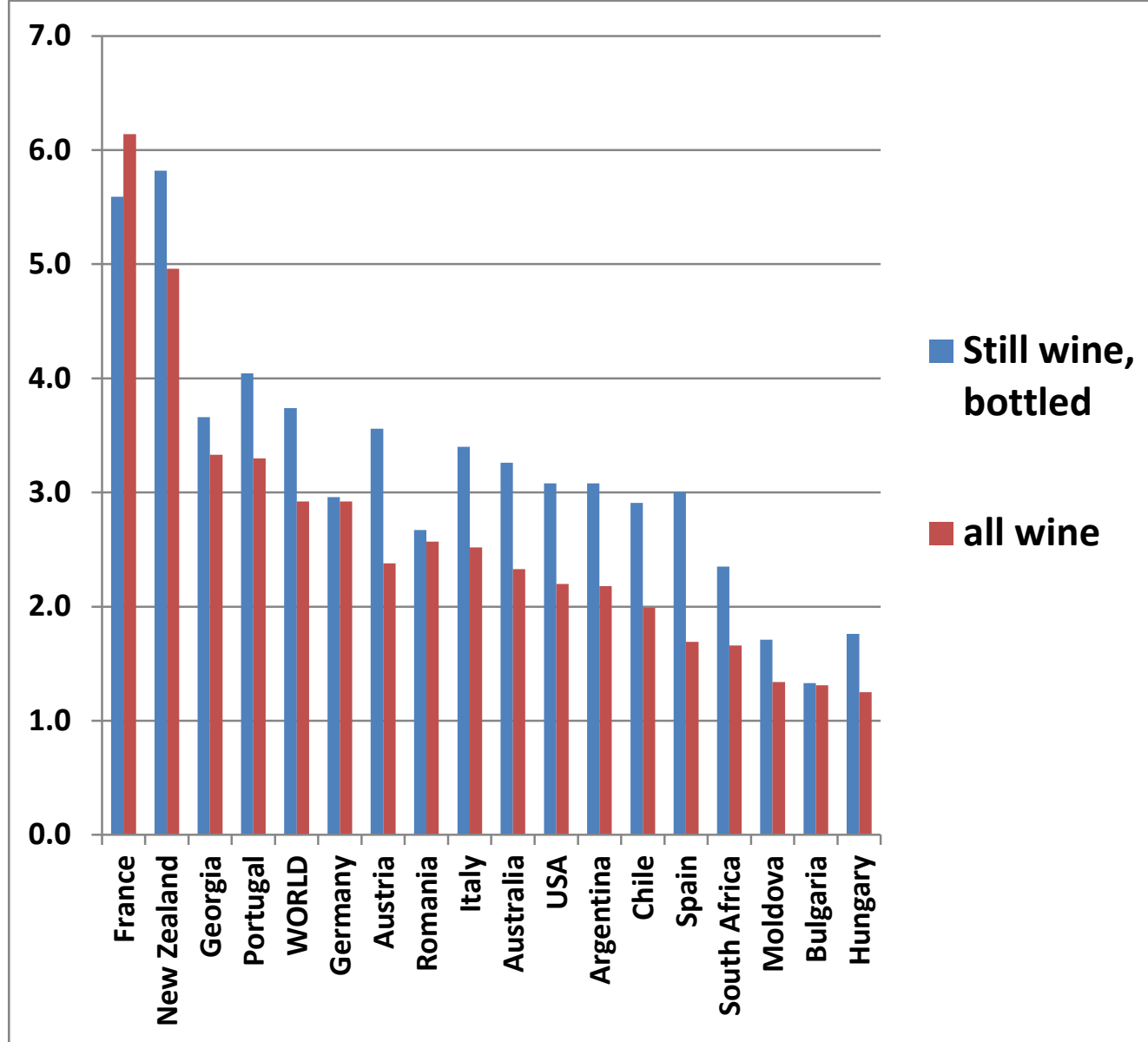

Source: Anderson and Nelgen (2011, Tables 76 and 79). 
Figure 9: Wine export volume and average price, Australia and Austria, 1965 to 2011

(a) Australia (million litres and Aust. cents)

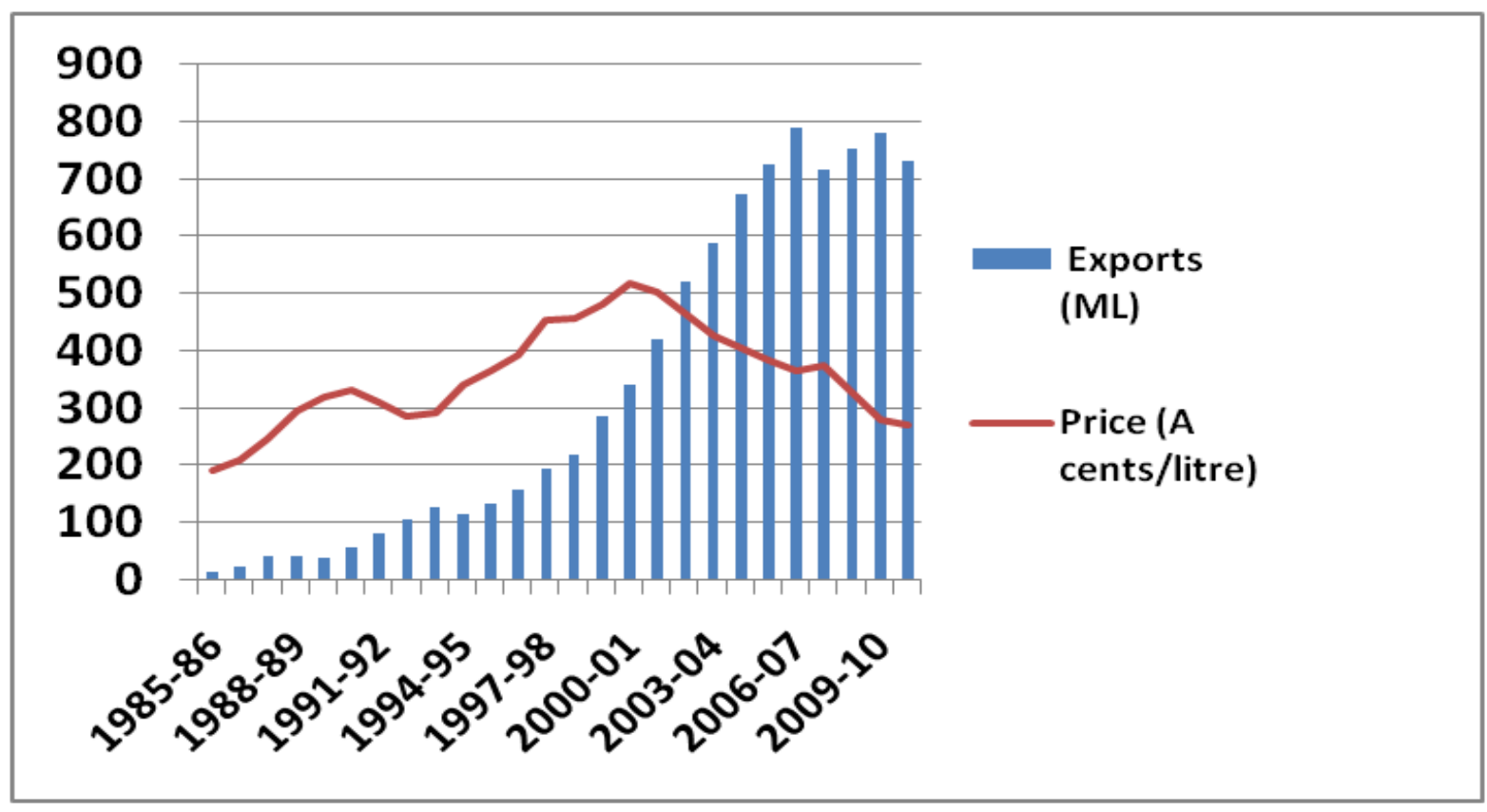

(b) Austria (million litres and US\$)

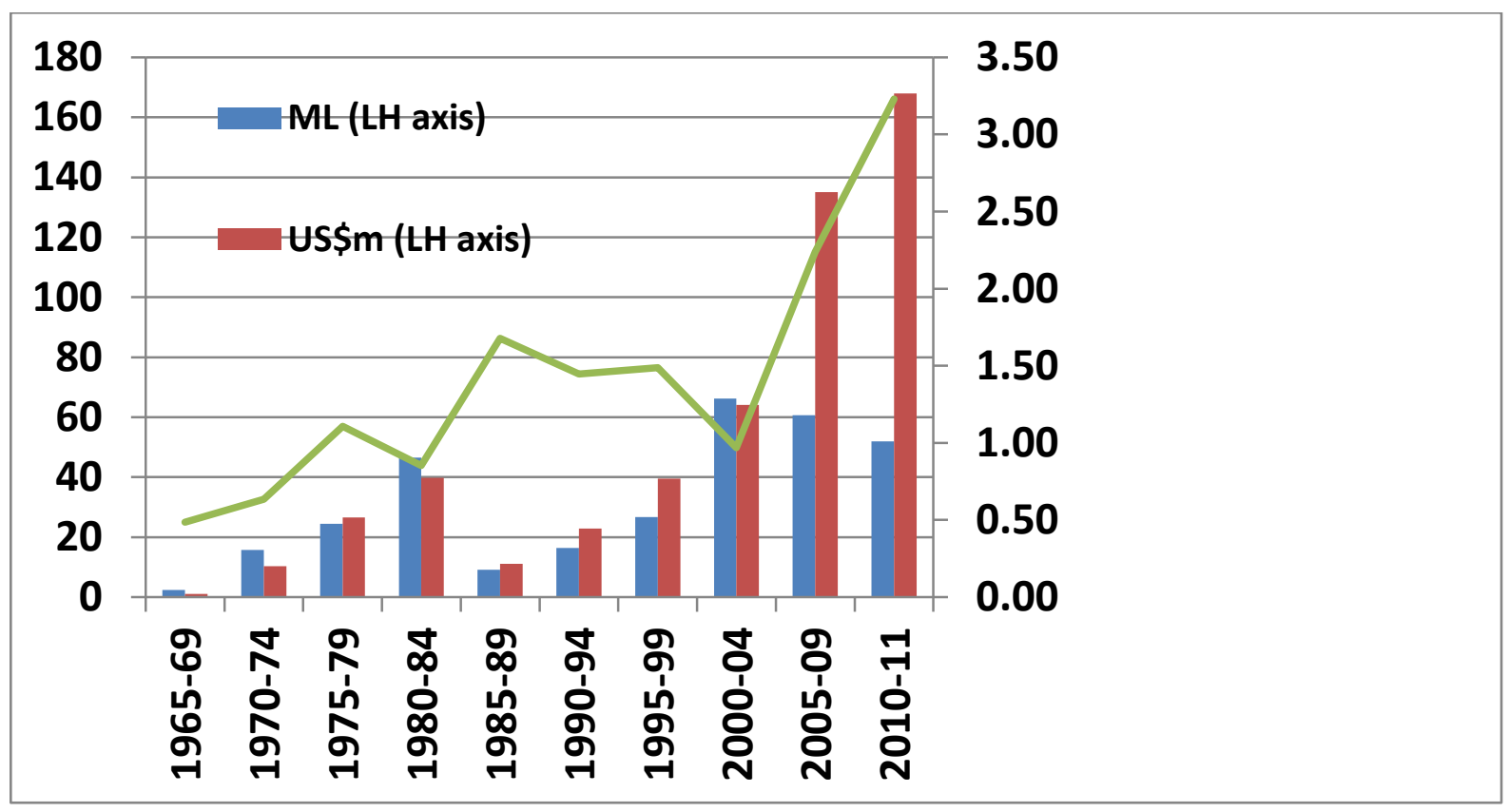

Source: Derived from data at the WINEFACTS part of www.wineaustralia.com and Anderson and Nelgen (2011, Tables 117 and 127). 
Table 1: Index of revealed comparative advantage in wine, ${ }^{\mathrm{a}}$ Georgia and 12 other top countries, 2000 to 2009

$\begin{array}{lrr} & 2000-05 & 2006-09 \\ \text { Moldova } & 96.1 & 45.9 \\ \text { Georgia } & 40.4 & 15.2 \\ \text { New Zealand } & 4.5 & 10.3 \\ \text { Chile } & 13.1 & 9.9 \\ \text { Macedonia } & 9.6 & 9.3 \\ \text { France } & 7.0 & 8.0 \\ \text { Portugal } & 8.2 & 7.8 \\ \text { Australia } & 8.5 & 7.0 \\ \text { Italy } & 4.4 & 5.0 \\ \text { South Africa } & 4.5 & 4.8 \\ \text { Argentina } & 2.7 & 4.6 \\ \text { Spain } & 4.4 & 4.4 \\ \text { Bulgaria } & 4.5 & 2.7\end{array}$

a Share of wine in value of national merchandise exports divided by share of wine in global merchandise exports.

Source: Anderson and Nelgen (2011, Table 75). 
Table 2: Volume, value and unit value of wine imports, and shares by quality, ${ }^{\mathrm{a}}$ selected countries, 2009

(a) Volume, value and unit value of wine imports

$$
\text { Volume (ML) Value (US\$m) Unit Value (US/litre) }
$$

$\begin{array}{lrrr}\text { China } & 173 & 457 & 2.65 \\ \text { Germany } & 1411 & 2770 & 1.96 \\ \text { Ukraine } & 17 & 47 & 2.77 \\ \text { United Kingdom } & 1277 & 4258 & 3.33 \\ \text { United States } & 927 & 4190 & 4.52\end{array}$

(b) Share of volume, and value, of imports by quality ${ }^{\mathrm{a}}$ (percent)

China

$\begin{array}{rrrrr}\text { Non- } & \begin{array}{r}\text { Commercial } \\ \text { premium }\end{array} & \begin{array}{r}\text { Super } \\ \text { premium }\end{array} & \text { Sparkling } & \text { All wines }\end{array}$

--volumes

--values

Germany

--volumes

--values

Ukraine

--volumes

--values

United Kingdom

--volumes

--values

United States

--volumes

--values

WORLD

--volumes

--values

$\begin{array}{ll}46 & 50 \\ 14 & 75\end{array}$

$52 \quad 41$

$18 \quad 59$

27

7

24

8

25

5

37

11

\section{0}

41
59

67

79

67

69

62

65

50

58

\section{3}

8

1

3

100

100

100

100

$\begin{array}{rr}5 & 100 \\ 17 & 100\end{array}$

2

100

100

100

100

100

100

100

100

${ }^{\mathrm{a}}$ The boundaries between the three still wine categories are US\$2.50 and \$7.50 per litre pretax at the border. The global average import unit values per litre thus escalate across that range, from around US\$0.90 for non-premium to \$3.60 for commercial premium and $\$ 7.25$ for super-premium (and \$8.20 for sparkling wine, or \$4.50 if French Champagne is excluded).

Source: Anderson and Nelgen (2011, Section VI). 
Table 3: Shares of 4 largest firms in domestic wine sales, Old World, New World, and transition economies, 2009

(percent)

\begin{tabular}{|c|c|}
\hline Largest firm & $\begin{array}{l}2^{\text {nd }}-4^{\text {th }} \\
\text { largest firms }\end{array}$ \\
\hline
\end{tabular}

Old World

$\begin{array}{lccc}\text { Austria } & 5 & 7 & 88 \\ \text { France } & 11 & 5 & 84 \\ \text { Germany } & 1 & 3 & 96 \\ \text { Italy } & 6 & 4 & 90 \\ \text { Portugal } & 62 & 23 & 15 \\ \text { Spain } & 11 & 10 & 79\end{array}$

New World

Argentina 27

32

41

Australia

23

39

38

Chile

31

51

18

New Zealand

24

24

52

South Africa

34

4

62

United States

21

35

44

Transition economies

Bulgaria

13

26

61

Hungary

8

7

85

Romania

11

21

68

Russia

6

11

83

Ukraine

16

28

56

Source: Anderson and Nelgen (2011, Table 33), based on Euromonitor International data. 